\title{
MĀRCIENA - BETWEEN LEGACY AND NOSTALGIA
}

\author{
Ilze Boldāne-Zeḷenkova \\ Institute of Latvian History \\ University of Latvia, Latvia \\ e-mail: Ilze.Boldane-Zelenkova@lu.lv
}

\begin{abstract}
In 1993, after the Soviet army's withdrawal, the local municipal government of the tiny Latvian village of Mārciena had to take over a former residential district of the Soviet officers' families, called Gorodok, and the infrastructure of the Soviet army unit that was located in the nearby forest. Over the past twenty years, the municipality has tried to find the best solution to protect the site from decay. Businessmen have attempted to raise the profile of the area, and all of the residents have reshaped their identities within the framework of economic and political developments taking place in the country. The purpose of the article is to examine these processes of making sense of the place called Mārciena from different points of view.
\end{abstract}

Keywords: Latvia, Mārciena, nostalgia, post-Soviet military base, Soviet legacy, uses of the past

During the Soviet occupation period, a very large number of military objects were located in Latvia. Between 1944 and 1991, there were at least 777 Soviet military sites in the territory of Latvia. The total number of military personnel was around 60,000 (Upmalis et al. 2006: 118). This fact justifies the use of a phrase in Latvian historiography: "Latvia - the USSR military base" (ibid.). The military bases of the Union of Soviet Socialist Republics (USSR) were located in sites previously used for military purposes (infrastructure built for the purposes of the tsarist Russian army, and garrisons of the army of the Republic of Latvia established during the inter-war period), as well as in newly constructed areas, on plots of land nationalised from residents of Latvia, thus introducing new features into the Latvian landscape. The military object to be discussed in this article, a base built in the parish of Mārciena in 1957, was one of these new sites. The purpose of the article is to examine this territory as an arena for negotiating visions of the recent past, as well as options of the local municipality for using the past as a resource for the development of 
the settlement. Research projects and collections of documents on the Soviet army withdrawal from Latvia in $1994,{ }^{1}$ publications in mass media, statistical data and experts' interviews provide a basis for a description of Mārciena's socio-economic situation. The fieldwork took place during three days in May and June 2015. In some cases, interviews were conducted via the Internet. The respondents were inhabitants of Mārciena, from forty-five to eighty years of age.

The location of military objects has, to a great extent, determined their future in the independent Latvian state, according to at least three scenarios: 1) they have been used for their intended purposes as garrisons of the Latvian military forces or residential areas, 2) they have become abandoned ghost towns, or 3 ) the buildings and territories have been adjusted to various needs, most often for the needs of cultural institutions or forest industry enterprises. The adverb "partially" should be used here, as the whole military complex has not always been employed for new purposes.

Unattractive scenery has been the result of various factors. First of all, Latvia does not need so many specific military objects, and therefore their maintenance is financially difficult. Secondly, Latvia features negative natural population growth and the population has also declined because of emigration to the western member states of the European Union (EU) (Cimdina \& Raubiško 2012; Dzenovska 2011, 2013). Hence, there are not enough people to fill the housing left by the vast masses of the Soviet military personnel and their dependants. Thirdly, the economic situation of Latvia as a whole has limited the opportunities for local municipalities to take care of such degraded territories (above all, to prevent further degradation), and has affected the ability of the population to financially support the sites, especially in rural areas. A final barrier is the negative attitude of Latvian society toward its recent past and the post-Soviet legacy. ${ }^{2}$

The Soviet military objects built in Latvia during the years of communist regime do not have any cultural-historical value in the eyes of the Latvian state. They are not classified as state-protected historical monuments. A different situation involves the Daugavgrīva fortress, the Daugavpils fortress, Liepājas Karosta ('War Port'), and other complexes used by the Soviet army, which were built during previous historical periods: when Latvia was a part of the Russian Empire, and during the twentieth century inter-war period. The Soviet legacy - either material or intangible - has been perceived by most members of society as a burden, as something that society has to learn to deal with and that has negative associations: pollution, unwanted neighbours, changes in Latvian landscape, inexpressive architecture, etc. Ex-territorial military areas as a topic worth analysing occurs in the local and national media rather than in academic discourse. So far, the analysis of the communist regime and its 
consequences for Latvian historiography has been undertaken mostly from the viewpoint of political history (for example, the series of works "Symposium of the Commission of the Historians of Latvia", in twenty-eight volumes ${ }^{3}$ ), and it was only at the beginning of the twenty-first century that other topics beyond those mentioned above were included. For example, during this time several valuable research projects analysing the split collective memory of Latvian society, including the conflicting remembrances of World War II and post-war events, were carried out (Muižnieks \& Zelče 2011; Neiburgs \& Zelče 2012 [2011]).

The ethnic composition of the Latvian population has also been perceived as a legacy of the Soviet occupation regime. The 1989 population census showed that the proportion of Latvians in the Latvian Soviet Socialist Republic (LSSR) was no more than 52\% (Mežs 1994: 67). Other nationalities living in the LSSR gave preference to the use of the Russian language, as it was the official language in the USSR. This situation created a large group of residents of Latvia today called the Russian-speaking population. The latest census data showed that the Latvian population was $62 \%$ Latvian and 29\% Russian (Centrālās statistikas 2011). Working on the guidelines of the state integration policy, experts pointed out this problem, indicating that there were two different viewpoints regarding the twentieth century history of Latvia, especially with reference to the years of the communist regime (Ziemele 2001; Dribins \& Šnitnikovs 2007). The main problems were connected with the question of whether it was an occupation of Latvia or a voluntary incorporation into the USSR, a question closely related to the identity of a part of Latvia's Russian-speaking population. Who are they: "occupants" or "liberators"?

Another node is connected with the Latvians who fought on the side of the Nazis during World War II, and are commemorated every 16 March with a procession in Riga and other places. Despite it being determined that they were coerced to fight by the Nazi occupation power (see, e.g., Neiburgs 1999), ${ }^{4}$ those men are perceived as fascists by the neighbouring Russian Federation and the Russian-speaking population of Latvia. Since 1998, when the Foreign Ministry of Russia expressed strong condemnation of "Nazis marching in the streets of Riga" (Muižnieks \& Zelče 2011: 146), more or less sharp confrontations between the participants in the commemoration event and members of "anti-fascist" groups at the Monument of Freedom have taken place. Currently a degree of tolerance regarding the existence of alternative views related to the events of Latvian history can be observed, and celebrations of the end of World War II on Victory Day, 9 May (Den' Pobedy) with boisterous picnics and loud fireworks are perceived by the Latvian majority as a ritual necessary for the identity of one part of the society, which is related to articles 103 and 104 of the Latvian Constitution (LR Satversme 1922) on the freedom of assembly 
and the rights of ethnic minorities to cultivate ethnic and cultural uniqueness. ${ }^{5}$ The only disputed point is the participation of state and municipal officials in those celebrations, as in the official calendar of Latvia May 8 is Memorial Day, marking the defeat of the Nazis and commemorating World War II victims (Ločmele \& Procevska \& Zelče 2011).

Despite the presence of new topics related to the communist regime in the Latvian historiography, there is a lack of evaluation of the fate of former Soviet military complexes. One of the tasks of this article is to contribute to the Latvian historiography by opening a discussion on this topic. The theoretical framework of the study is formed by works of authors who examine key areas of the chosen topic: post-Soviet bases in Central and Eastern Europe (Demski \& Czarnecka 2015), senses of place (Ashword \& Graham 2005), communities of memory (Halbwachs 1950; Kaprāns 2013; Truc 2011), legacy and uses of the past (Lowenthal 1985; Noyes 2016) and nostalgia (Boym 2001).

The framework of the present analysis is shaped by a few key notions. As these notions can be defined in different ways, it is necessary to first explain how I understand them. On the notion "uses of the past", I share the position of David Lowenthal (1985) regarding the traits that make the past helpful to people, making it possible to locate lives in linear narratives that connect the past, present, and future, and to use these narratives as economic resources.

The term "senses of place" herein is understood as products of the creative imagination of the individual and of society. Different people at different times and for different reasons create different narratives of belonging; thus heritage is as much about forgetting as about remembering the past (Ashword \& Graham 2005: 3).

The notion "legacy" is a proper term and discursive practice referring to remnants of the Soviet past, and is used as such in this study about Mārciena. Here I am using the definition given by Dorothy Noyes (2016: 388), who says that "legacy is what you keep on life support because you can't afford to kill it off".

The narratives of local people and an interview with the head of the local government led me to pay attention to nostalgia. Nostalgia is the object of many investigations in various scientific disciplines (e.g. sociology, psychology, and literature), which use many forms of the term: "restorative" and "reflective" nostalgias (Boym 2001: 49), "official" and "non-official" nostalgias, "private" and "collective" nostalgias (Davis 1979: 122), and "mobile" nostalgias (Bonnett \& Alexander 2013). Nostalgia, in the sense of a "longing for what is lacking in a changed present... a yearning for what is now unattainable, simply because of the irreversibility of time" (Pickering \& Keightley 2006: 920), is a central notion that permeates present-day discourses and practices (Angé \& Berliner 2016 [2014]: 2). 


\section{HISTORY OF MĀRCIENA}

To use Maurice Halbwachs's (1950: 2) term, the places where the Soviet military bases were built were not "empty blackboards". Mārciena is a small parish in Madona County; according to the latest census data, from 2011, it had 984 inhabitants. ${ }^{6}$ The history of the parish under the name Marxne dates back to the thirteenth century (Liniņš 2013). Before 1957, it had never been used for military purposes. For centuries, the Mārciena parish territory was the property of Baron Tiesenhausen's family. The last owner of the Mārciena estate was Baron Woldemar von Maydell, Landrat of the Vidzeme province. The manor house of the estate was burnt down during the revolution of 1905 . According to a popular legend, fearing the establishment of Soviet power, the baron burnt the manor house and committed suicide in 1918.

During the inter-war period, as elsewhere in the rural regions of Latvia, the main economic activity in Mārciena parish was agriculture, and the processing of such agricultural products as flax, milk, and grains (Liniņš 2013; Iltnere 2002: 30-33). Mārciena railway station, built on the Plavinas-Valka line in the inter-war years, provided an important stimulus for the further development of the settlement.

The largest concentration of the population and hence the development of the parish and village took place in the second half of the twentieth century, during the years of the communist regime in Latvia, and this was due to several socio-economic factors and political aims of the regime. The ideological course of the USSR, directed against private property, and an economy oriented towards collectivisation eradicated the individual farmsteads characteristic of the Latvian cultural-historical landscape, creating kolkhozes and kolkhoz villages. Kolkhoz villages formed on the basis of existing villages (in the case of Mārciena, it was a settlement that evolved near the centre of the Mārciena estate) and were complemented with new buildings constructed according to model projects, e.g. "Livani houses" or multi-storey blocks of flats. One of the kolkhozes established in Mārciena, Zelta Druva ('Golden Field', 1949), specialised, among other things, in fur animal breeding, which demanded the involvement of professionals. Specialists were also needed for the branch of the chemical manufacturing company Aerosols (est. 1964).

However, the biggest changes to the landscape of the site and to the size and ethnic composition of the local population were caused by the building of a military base ${ }^{7}$ (1957) in the forest, two kilometres from the village, and a residential area for officers' families, located nearby. The River Ārona formed a natural border between the two parts of Mārciena: on one of the banks was the residential area of the officers' families and on the other the kolkhoz village. 
Similar to a practice common in other residential areas of the Soviet military personnel in Latvia, a (re)naming of the site took place in Mārciena. New names of places were usually in the Russian language because of the ethnic background or native language of the residents. ${ }^{8}$ The name Gorodok ('township') was chosen and used by the inhabitants of the site instead of the official name of the officers' residential area, Mārciena 2, and it was also accepted by the people of Mārciena on the other side of the River Ārona. Gregory Ashworth and Brian Graham (2005: 16) note that naming places is both a necessary means of recognition and communication and a fundamental means of laying claim to territory. The definition of a place can be a part of the broader processes of inclusion and exclusion (Reid 2005: 48). It is a question of belonging to the place and of opportunities to use benefits offered by it. Although the residential complex in Mārciena was not an enclosed area surrounded by physical walls, and the local people worked there and could freely attend the cultural events organised there, the Soviet system itself and the data from the interviews reveal the existence of a border between "us" (family members of the military personnel) and "them" (local people, mostly Latvians).

The establishment of the Soviet military base was a vivid event in the local history, associated with at least two legends revealed in conversations with the local population and in interviews with people outside Mārciena, whose lives were also connected with the Soviet military facilities in Latvia. The first story was about the intention to build a secret, strategically important, nuclear missile base in Mārciena. However, "betrayer Penkovsky" thwarted those plans. The US intelligence service found out about it and therefore the idea was abandoned. Thus a less harmful unmanned aircraft aviation and personnel training centre was established in the forests of Mārciena. Oleg Penkovsky was a real person: a colonel in the Soviet military intelligence who collaborated with the intelligence services of the United Kingdom and the USA. In 1963 he was arrested by the Soviet authorities and executed (Schecter \& Deriabin 1992: 284). Another story was associated with a situation assessment related to ongoing construction work carried out in the nearby forest in the second half of the $1950 \mathrm{~s}$, and is attributed to a locally respected and highly appreciated educator, who said: "It was a marsh and will be a marsh!" Everyone who heard this, whether in the Latvian or Russian language, admitted that he was absolutely right. Something built in a marsh is doomed from the beginning.

Within approximately thirty years, until the withdrawal of the Soviet army, ten five-storey blocks (420 flats), a hotel for officers, a kindergarten, a library, a sports hall, a swimming area, and a shop selling food, as well as household and industrial commodities significantly different from those on sale on the other side of the River Ārona, were built in the residential area. The local kids 
whose native language was Russian attended the secondary school with Russian as the language of tuition, opened in the officers' residential area in 1964. The school for Latvian children with Latvian as the language of tuition was some distance from the centre and it was located in two buildings. Segregated stores and spetsobsluzhivanie ('special service') were characteristic of the communist regime and emphasised the special status of the party members and military personnel in the country. Latvia was not an exception.

After the collapse of the USSR, as in other places in the post-Soviet space, Mārciena inhabitants on both sides of the river (former military and civilians) faced great challenges created by the replacement of the Soviet socio-political system with a neoliberal one, which brought about a total collapse of both their economic system and social networks (Annist 2014: 101). The elimination of the kolkhoz and the Soviet military base led to unemployment. The state structures - the municipal government, school, kindergarten, library, and holiday house (which in 2016 became a nursing home) - now provide jobs for local residents. The Soviet mentality, lack of initiative (ibid.: 91) and unpredictable state tax system impeded the creation of private companies in the countryside. The withdrawal of the former Soviet army (since 28 January 1992 the Russian Federation Army) from Mārciena caused changes in the environment, and in the composition of the population, and left behind empty flats in the former residential area Gorodok (now Meža Street), which the local families characterised as disadvantageous. A respondent who had lived in the Meža Street district since it was built, stressed that blocks of flats in good condition attracted people from all over the country, and this brought about many social problems. "The train would arrive, a family would get off, and go to one of the empty flats. They would live there for a while and then leave in order not to pay the rent." 9

\section{THE ARMY IS GONE, BUT ITS LEGACY REMAINS}

In 1991, independence was restored in Latvia and the requirement to withdraw the Soviet (later the Russian Federation) army from its territory was a logical consequence. Intergovernmental negotiations were long-lasting, at times destructive, and their price was high: no restitution for the polluted and littered land and forest areas, 25,000 of the retired military personnel ${ }^{10}$ would remain in Latvia and be given social guarantees, etc. (Jundzis 2014: 12-13). To rid the country of the presence of the foreign army was the highest priority at that time. In 1993, the soldiers, officers and their family members located in Mārciena left the country. According to the data provided by the head of Mārciena parish, some eight or ten families of retired officers chose to remain under conditions of intergovernmental agreements ${ }^{11}$ regarding army withdrawal. 
Mārciena is one of the numerous ex-territorial areas in Latvia facing similar problems: the preservation and maintenance of buildings, removal of ruins, the need for improvement in natural and social environments, and difficulties in retaining human resources. The Mārciena municipality focused on solving the problems related to the post-Soviet legacy by selling the forest areas in which the infrastructure of the former Soviet military base was located. The parish got rid of the territory by selling it to local timber businesses. ${ }^{12}$ According to the land reform of the $1990 \mathrm{~s}$, part of the territory was also given back to private owners. The buildings of the former military base, with the exception of hangars which are used for the timber business, have fallen into ruin (Figs. 1 and 2).

The former residential area of the family members of the military personnel experienced large changes in population ${ }^{13}$ triggered by coincidence and the practice of sending to Mārciena "unfavourable" families from all of the parishes of Madona County, ${ }^{14}$ a plan developed by the Madona County government. These new inhabitants are believed to have had a disruptive impact on the condition of the surrounding buildings: windows broken, wooden parts removed and used as firewood, etc. As was stated by the current head of the municipal government, migration and changes in the population were huge at that time, and social problems still partially remain (Figs. 3 and 4).

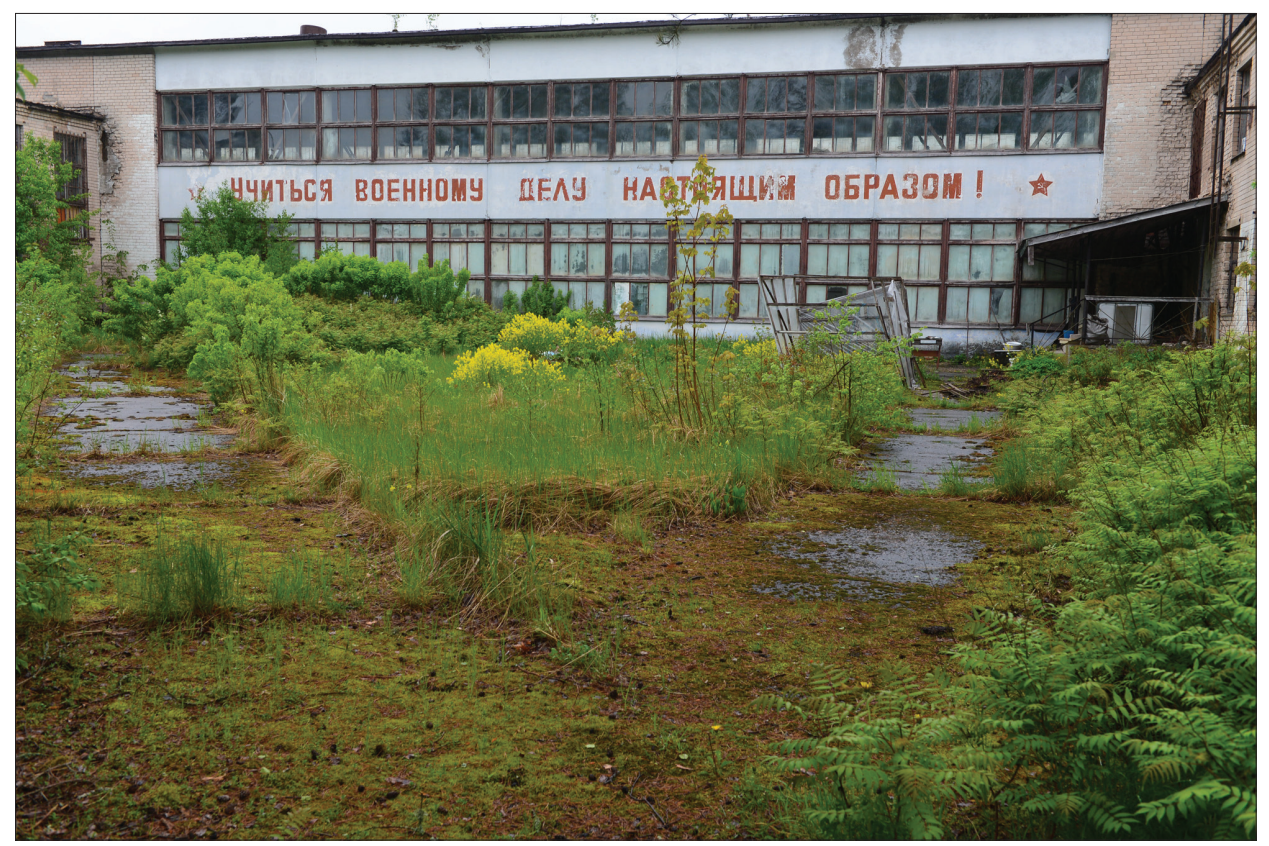

Figure 1. Post-Soviet military base in the Mārciena forest. The slogan on the wall, "To learn the art of war properly!", is a quote from a 1918 speech by V. I. Lenin. Photograph by Dagnostaw Demski 2015. 


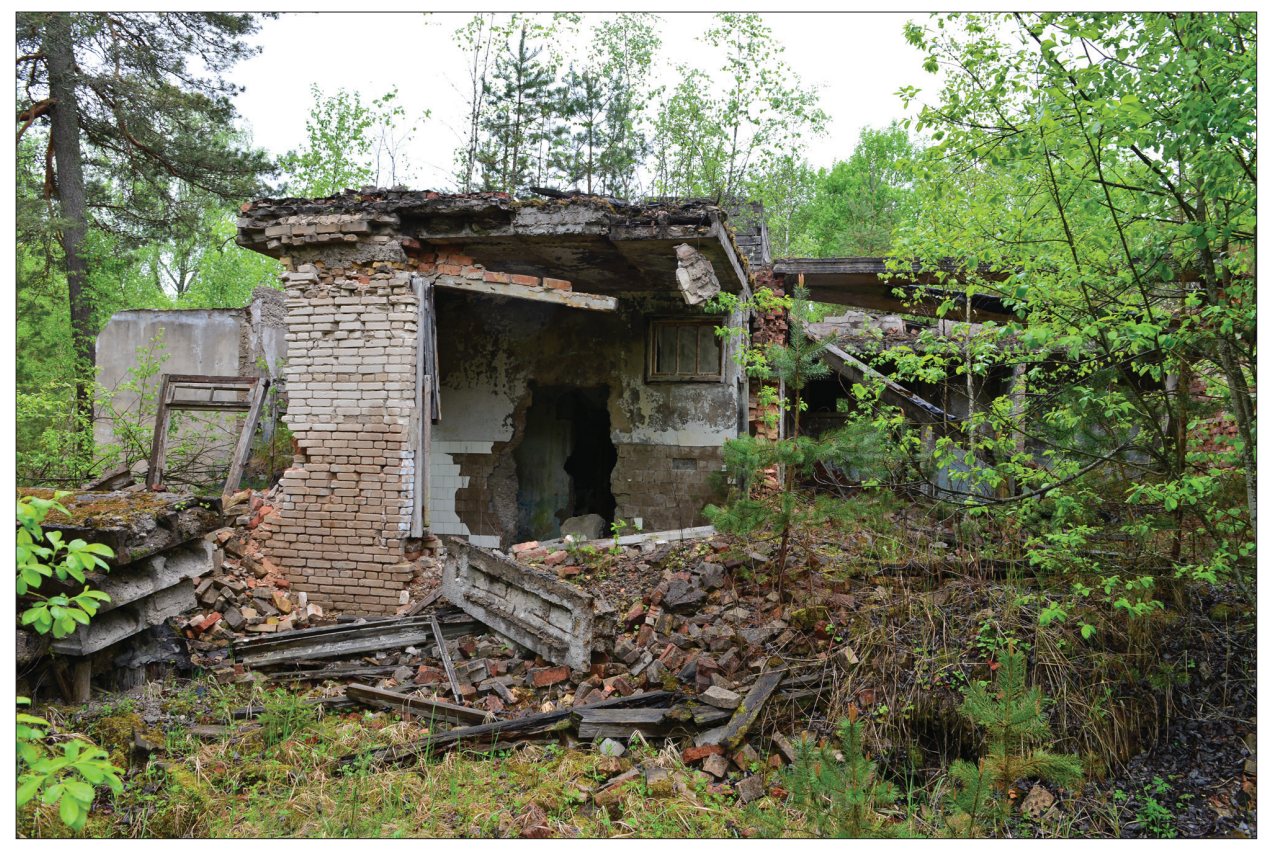

Figure 2. Post-Soviet military base in the Mārciena forest. Photograph by Dagnostaw Demski 2015.

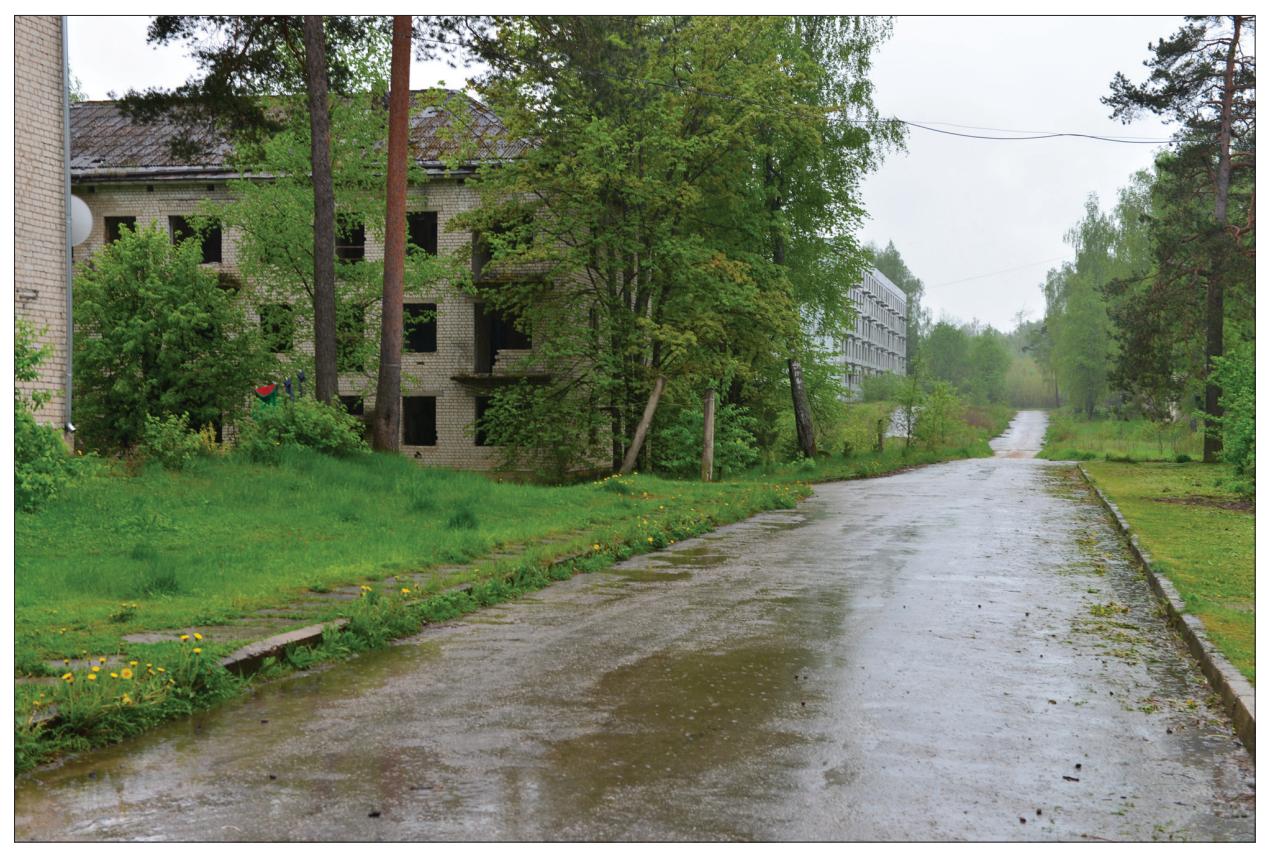

Figure 3. The left side of Meža Street in Mārciena (former Mārciena 2). Photograph by Dagnostaw Demski 2015. 


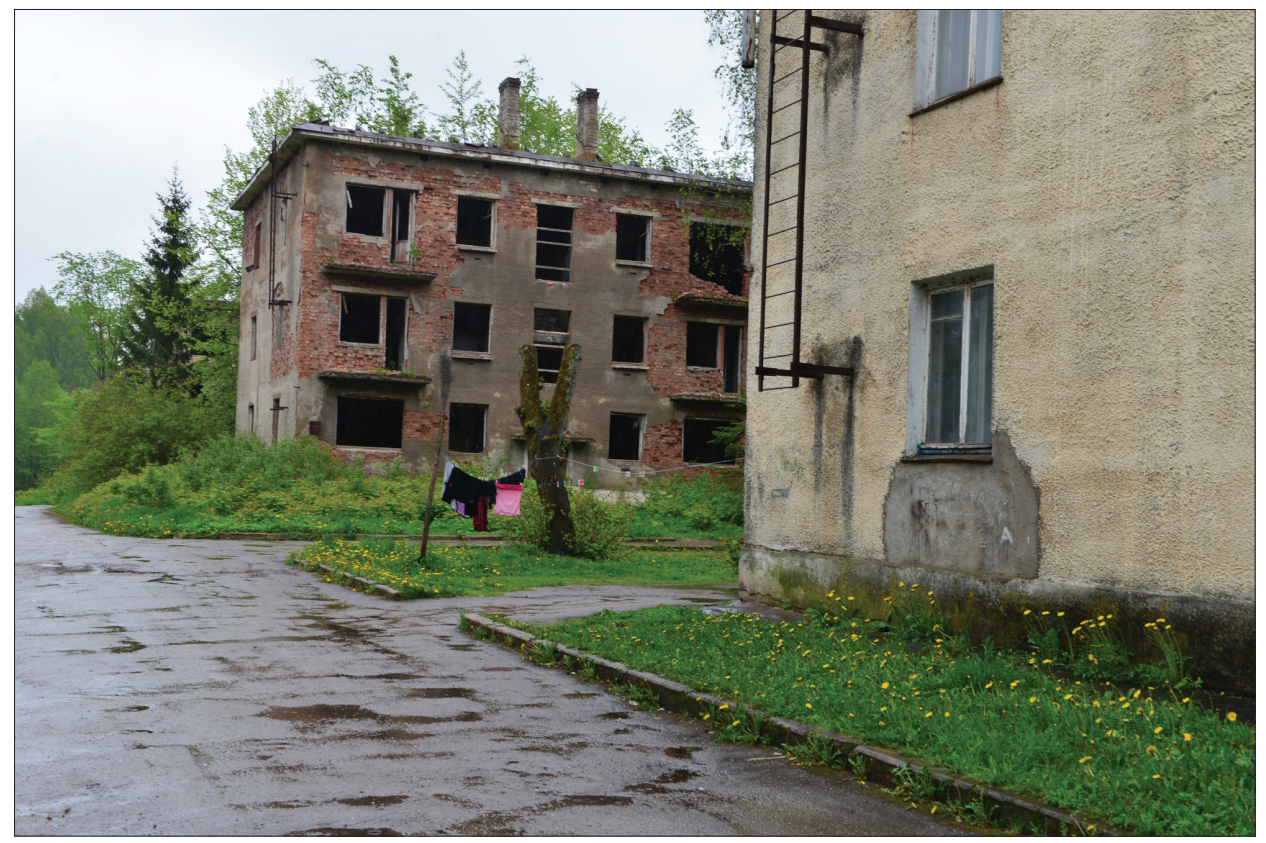

Figure 4. The right side of Meža Street in Mārciena (former Mārciena 2). Photograph by Dagnostaw Demski 2015.

The municipal government aims to revitalise this place, to make it attractive as a residential area and thus to increase the revenue of the municipality. Local governments have participated in several European Union projects, including the international EU project INTERREG III B Baltic Sea Region programme project ReMiDo (2005-2007), the purpose of which was to facilitate the role of the state and municipal governments, private and non-governmental organisations, and to increase the development of residential areas by applying the experience of other countries. Five countries - Lithuania, Estonia, Germany, Poland, and Sweden - participated in the project along with Latvia (Pukīite 2006, 2007). Despite the fact that due to their critical technical condition seven out of ten blocks of flats are awaiting demolition (the municipality does not have the financial means to undertake this), all of the public buildings - a school, a club, and a hotel (till 2015 a former kindergarten, and currently a nursing home for sixty-one people from all over Madona County) - have been preserved, renovated, and are still functioning. 


\section{MĀRCIENA AS A TOURISM SITE: POTENTIAL AND MISSED OPPORTUNITIES}

While, as mentioned above, the municipality put effort into finding the best ways to use the post-Soviet legacy to increase its revenues, as well as improving the well-being of the population, local businessmen, driven by economic interests, worked to improve the profile of the site. Among other local sightseeing objects, local businessmen supported the restoration of St. Aleksey Orthodox Church and the creation of the symbolic stone dedicated to the 800th anniversary of Mārciena.

In terms of Mārciena's status in the context of other Latvian sites, the first thing the place is associated with is the phrase "Mārciena estate", which under closer examination turns out to be just a brand: the name of the spa resort and a popular recreation place, having a distant connection with the Mārciena manor, which belonged to Baron von Maydell. It should be noted that the promotion of the brand "Mārciena estate" aroused loud polemics between historians and the owner of the property on the uses of the name "Mārciena estate" and the creation of myths about it (Zvirgzdiñ š 2003). The fact that the widely advertised spa resort is situated in the former merchant's residence, Patmalnieki (a school until 1994), and not in the building of the Mārciena manor, triggered this dispute.

Tourist sites in Mārciena parish include several nature and historical monuments: the Krustkalni nature park with a path to Lake Dreimani, the Mārciena manor buildings and park (1830), the renovated St. Aleksey Orthodox Church, built in 1872 (Iltnere 2002: 32), the memorial stone dedicated to the 800th anniversary (2013), etc. There are also two places connected with the Soviet occupation period: a memorial dedicated to repressed Mārciena residents and the Brethren Cemetery of the Soviet soldiers killed in World War II, which are significant ritual remembrance and commemoration places for different memory communities.

Some opportunities have been missed. In the list of tourist sites (see http:// www.marciena.lv/turisms-marciena), there are none connected with the former military base or those in the surrounding area related to it. This leads to two questions: "Should there be?" and "Why aren't there?". Skilfully communicated and promoted as a tourism product, it would be a good way to use the heritage of the recent past, and the local municipality could benefit from it. As a positive example, Borne Sulinowo (Poland) can be mentioned (Demski \& Czarnecka 2015).

There are several answers to the question of why this post-Soviet legacy is not used as a tourism product. First of all, the legal entities and private individuals who became owners of the forest areas around the former military base chose forestry rather than tourism as their business activity. The history of Latvia 
shows (e.g., regarding the former rocket base in Zeltini) that it is almost impossible for several owners to agree on establishing one tourism object, ${ }^{15}$ especially considering the low popularity of tourism related to the Soviet past (compared to Lithuania, where it is widely popular (Angé \& Berliner 2016 [2014]: 6-7)). Secondly, it is understandable that associating Mārciena with a complex of renovated buildings from the nineteenth century, the "Mārciena estate", about which the narrative has not been preserved in the memory of the local society, is more pleasant than associating it with the ruins of the former military base in the Mārciena forest or with empty houses in Mārciena's Meža Street.

There is also the question of supply and demand, and the willingness and efforts to promote the post-Soviet legacy as a tourism product, i.e., dealing with the wider social, economic, and political context and with forgetting and remembrance in the creation of the sense of the place.

The international situation (including the military conflict in Ukraine) and the warring memories in the Latvian public space still do not allow Latvians (even on the governmental level) to look at the Soviet past and post-Soviet legacy without suspicion. Military facilities that were built before the Soviet occupation and represented architecture of other epochs had higher status in the independent Latvian state. Many of them were assigned the status of cultural monuments of state or local significance, ${ }^{16}$ which proved that they belonged to the Latvian cultural heritage and accentuated their place and significance in the historical memory of the society (Mintaurs 2012, 2013): the Daugavgrīva fortress (2003), the Liepāja naval port (separate buildings: 2005 and 2010), the Daugavpils fortress (1998), and the Krustpils castle (1998). Facilities of this kind serve as clear evidence of the state's memory politics.

\section{GORODOK - RECOLLECTION WITH NOSTALGIA}

Past events in our memory are tightly connected with memories about the places where they happened. Maurice Halbwachs (1950: 14-15) refers to the intrinsic spatiality of memory, which can be explored through cultural and social practices, activities, and enactments, which symbolically reinforce or challenge the collective memories inherent in physical landscapes, practices that frequently provide the core emotional attachments, linking communities to their environments.

Every place can possess several senses connected with different historical periods and various communities of memory. People can be nostalgic for time or place, or a place in time. Svetlana Boym (2001: 21) acknowledges that nostalgia is not just mourning for an ideal past, but for the perfect present and its lost potential, and this is a key point in the context of the residents of Mārciena, who, as in Latvia as a whole, are divided into people belonging to 
different ethnolinguistic groups and memory communities. At the same time, these people accept and sometimes even share each other's feelings towards the native language and common past. Despite joyful expressions in the public space over liberation from the army presence, ${ }^{17}$ the residents of Mārciena vividly and with a certain nostalgia remember times in the village's history connected with the Soviet army's presence there: while the Latvian ethnolinguistic group have tried to escape from the present (Sedikides et al. 2008: 306), the Russian speakers mourn the loss of the power and privileges they had in the Soviet times. The common ground of both groups' narratives about Gorodok includes a yearning for the lost social well-being, a clean environment and good neighbours. It should be acknowledged that Meža Street is very well maintained, but the skirmishes have left an impression on the landscape.

In spite of the lack of a physical wall, the symbolic borders established by the socialist system between the inhabitants of the two parts of Mārciena were obvious. There were local people and people from Gorodok (an oasis), who did not experience deficits or other common daily problems. A family member of a retired officer emphasised the openness of Gorodok, talked about the possibility of purchasing goods in the specialised store, and said: "We shared our pleasures". ${ }^{18}$ No matter which group one belonged to, the memories of ladies wearing fur coats, of flower beds in front of the houses, and cultivated garden allotments are much more appealing than the present grey daily life. In interviews, the residents of Gorodok (the Russian-speaking group) stressed the positive self-evaluation and recognised position in the society at that time compared with now, constantly being on the defensive regarding their language skills, their reasons for staying in Latvia, etc. Sociological studies have revealed that the change in the social status of the Russian-speaking group was a traumatic experience for them (Apine \& Volkovs 2007; Hanovs \& Vinninika 2006: 205).

The term "mobile nostalgias" was coined "to open up the complex relationship between the city and those who have left it" (Bonnett \& Alexander 2013: 391). People who completely share a longing for the memory community of the retired Soviet officials and their family members, i.e., for a lost past, are those who moved to Yegoryevsk, on the outskirts of Moscow, and to other places where they were assigned during the withdrawal of the Soviet armed forces. Mourning was connected with age (the time of their youth) and with the time of their privileged social status. Cyberspace, by making the bric-a-brac of nostalgia available in digital form, and making it more desirable than the real past (Boym 2001: 347), is an appropriate space for sharing nostalgia. Boym acknowledges that "on the blue screen two scenarios of memory are possible: a total recall of undigested information bytes or an equally total amnesia that could occur in a heartbeat with a sudden technical failure" (ibid.). Cyberspace as a site for meeting others is actively used both by those retired Soviet officials 
and their family members who stayed in Mārciena and by those who left. Narrative data are shared in conversations, using appropriate internet tools (the most popular being www.skype.com), through exchanging pictures, home-made videos and films representing symbolic memory sites, in social networks uniting classmates ${ }^{19}$ those who served in the same army regiment ${ }^{20}$ or in the aviation units of the Soviet armed forces, ${ }^{21}$ etc. Photographic and video memories are also posted on widely known internet sites (https://yandex.ru; www.youtube. com), thus passing along messages and appealing to those who belong to this community of memories, but are not in direct contact with it. On the internet sites mentioned by the respondents, there are photographs and videos in which the symbolic memory site is confronted with its current visually unattractive physical shape. ${ }^{22}$ Laconic titles, the lack of commentaries, and dramatic and appropriate background music express the emotions that the authors of the videos have experienced. In the case of Mārciena, the author has chosen "Toccata and Fugue in D Minor" by Johann Sebastian Bach. This particular video can be found on many internet sites where the former military personnel of the USSR and the Russian Federation or their family members share their traumatic experiences in confronting symbolic memory sites and the ghost towns they have turned into. ${ }^{23}$

For former inhabitants of the residential area, which they have named Gorodok, a nostalgic song by the same name performed by the Russian singer Angelika Varum has become a kind of anthem. ${ }^{24}$ The song starts with the words:

Akh, kak khochetsia vernut'sia,

Akh, kak khochetsia vorvat'sia $v$ gorodok,

Na nashu ulitsu v tri doma,

Gde vse prosto i znakomo na denek.

Oh, how I wish to return,

how I wish to enter the township.

To come to our street, to those three houses,

where everything is so simple and familiar. For one day...

It was chosen as the soundtrack for a video about the withdrawal of the former Soviet army from Mārciena, made by one of those who left the site. ${ }^{25}$ Cyberspace offers a sense of presence for both longing and celebrating, and the most significant feast for this memory community is 9 May, Victory Day. Sociological studies confirm the fact that Russian identity in Latvia is not homogeneous and is highly influenced by the state of affairs in the Russian Federation (e.g. Hanovs \& Viṇnika 2006: 205; Kaprāns \& Procevska 2013). This is the reason why most of the Russian-speaking community in Latvia celebrate the end of World War II not on 8 May, the official date in Latvia and other EU countries, but on 9 May, the same day as in the Russian Federation. Ilva Skulte has said: 
May 9th as a symbolic date was always in the centre of the mobilising Victory narrative in Soviet as well as contemporary Russia letting no place for Baltic reservations and opposition - for Balts, this day has equally symbolic meaning of (re)establishment of Soviet regime leading to the loss of an independent state and traumatic experiences of totalitarianism [sic]. (Skulte 2016: 13; see also Grigas 2013: 127-154)

There are no monuments to liberators or memorial ensembles dedicated to the victory of the Soviet army over fascism in Mārciena. The Brethren Cemetery ${ }^{26}$ of Soviet soldiers located near the town is used as a place of commemoration for the ritual celebration of the holiday. The situation in Mārciena differs from that in Latvia as a whole in that the head of the municipal government (in office since 2005), together with an Orthodox priest, participates in the celebrations out of a desire to show respect to all of the inhabitants of the parish and a wish not to divide them by language or political affiliation. In Latvia as a whole, only the left-wing political parties, such as the Saskanas Centrs, always participate in the Den' Pobedy, celebrated by the Russian-speaking population of Latvia on 9 May.

\section{CONCLUSION}

Twenty-four years ago, many Latvian local governments were faced, among a number of other serious issues, with a challenge: what should be done with the legacy of the Soviet army? The municipality of the small Latvian village of Mārciena had to solve this problem. The Mārciena municipal government had to take over the residences of Soviet soldiers' families, known as Gorodok, and the infrastructure of the Soviet army unit located near the forest. Since 1993, the municipality has been trying to find the best solution to protect the place from collapse. Local entrepreneurs, by developing their businesses, including tourism, have done much to promote Mārciena's image. All of the residents of Mārciena have tried to find their places and roles within the current economic and political development of independent Latvia.

The rapid transition from the Soviet economic system to neo-liberalism resulted in unemployment, shortages and, hence, apathy among the local population, and this did not make it easier for the municipality to solve the problem of the post-Soviet legacy. European Union funds and financial support from the government of Madona County made it possible to rebuild and utilise several buildings in the former residential area, thus using the past's heritage for the benefit of the community. Unfortunately, part of the housing, as well as the former military base buildings in the woods - historical remnants - have continued to deteriorate. 
The past was also used to search for business opportunities in Mārciena and to create significance for the site. The spa resort located in the former school building (from the nineteenth century) used the well-known but pretentious name "Mārciena Manor". This demonstrated the spirit of the time when it was popular to modernise manors and remember the contribution of the Baltic Germans to the development of Latvian cultural environment.

The change in political power resulted in changes in topography; the place name from the Soviet period was replaced by a new one: Meža Street, Mārciena. Nevertheless, Gorodok continues to exist in the memories of Mārciena residents as a symbol of a certain space of time.

The difficult transition from socialism to capitalism brought poverty, low selfconfidence, and loneliness for many rural inhabitants, which in turn triggered nostalgia. Despite belonging to different ethnolinguistic groups and memory communities, both groups of Mārciena residents are nostalgic: military retirees longing for the lost past and their lost status, and locals yearning not for a return of the past but for something better than the present difficulties. Both groups long for an orderly environment, for the order present in Gorodok during the Soviet era.

Cyberspace, providing the opportunity to virtually share longings for the past and to celebrate the holiday, can unite everyone connected to Mārciena: both the local residents and those who left Mārciena in 1993. Similar to other places in Latvia, there is also a memory place in Mārciena, where on 9 May, together with people sharing a similar interpretation of the past based on Soviet historiography, Victory Day is celebrated, which is also supported by the municipal government. In conclusion, I would like to quote Svetlana Boym's statement (2001: 354-355), which I agree with:

Nostalgia can be both a social disease and a creative emotion, a poison and a cure. The dreams of imagined homelands cannot and should not come to life. They can have a more important impact on improving social and political conditions in the present as ideals, not as fairy tales come true. Sometimes it's preferable (at least in the view of this nostalgic) to leave dreams alone, let them be no more and no less than dreams, not guidelines for the future.

\section{ACKNOWLEDGEMENTS}

The author's work on this article constitutes a part of the UL project No. AAP2016/ B060. The author's special thanks go to Ināra Mālniece, the head of the Mārciena parish government, Aldona Gudrīte, the director of the Mārciena Elementary School, and all respondents who shared their thoughts with her. 


\section{NOTES}

1 The process of withdrawal lasted from 1991 to 1994 . Although according to the official agreement the final date for withdrawal was 31 August 1994, the Skrunda radar station remained in Russian hands till 1998, after which Russians had eighteen months to dismantle it.

2 The social memory monitoring published in Latvia in 2013 showed that a significant part of the Latvian society tolerated the co-existence of different opinions regarding the events of 1940 and the whole Soviet period, permanently represented by at least two communities of memory. Assessing the period of the communist regime in Latvian history, ethnic Latvians had shifted from a negative attitude to a pragmatic and neutral position, while the attitude of the Russian-speaking population of Latvia had become more positive towards this period (Kaprāns \& Procevska 2013; Kaprāns 2013). It should be mentioned that this monitoring was carried out in 2012 , but events in Ukraine, where in certain situations clear similarities with the events in Latvia in 1940 can be observed, in my viewpoint have significantly damaged that neutral attitude towards the period of the communist regime and the Soviet era in Latvia.

3 The Commission of the Historians of Latvia was founded in 1998 on the initiative of the then president of Latvia, Guntis Ulmanis. The aim of the commission was and still is to conduct detailed research on the politics of the Nazi and Soviet regimes (see http://www.president.lv/pk/content/?cat_id=7; last accessed on September 25, 2017).

4 By forming the Latvian Volunteer SS Legion, the Nazis violated the Fourth Hague Convention (from 1907, on the Laws and Customs of War on Land) and thus committed yet another war crime (Krūmiňš 2017: 6). There was no volunteering. Those who did not enlist during the announced mobilisation were imprisoned in concentration camps for six months and then sent to the legion. Later on, the death penalty was imposed for evading mobilisation.

5 Article 103: "The State shall protect the freedom of previously announced peaceful meetings, street processions, and pickets"; Article 104: "Persons belonging to ethnic minorities have the right to preserve and develop their language and their ethnic and cultural identity" (LR Satversme 1922).

6 See the Central Statistical Database, available at http://data.csb.gov. lv/pxweb/lv/tautassk_11/tautassk_11__tsk2011/TSG11-01.px/table/ tableViewLayout2/?rxid=6b213b07-c02d-49b7-badb-3d7ced80fdff, last accessed on September 25, 2017.

7 Military units based near Mārciena: No. 10211-275 - Separate Unmanned Aircraft Squadron; No. 22799-14 - Separate Unmanned Reconnaissance Plane Squadron; No. 14154-924 - Military Training Centre for Personnel; and No. 68505 - a separate Baltic Fleet Sea Squadron, established in 1957 (Upmalis et al. 2006).

8 In Alūksne, for instance, it was Lugovcovo (by analogy with the street name), and in Krustpils it was Zamok ('castle'): this name was determined by the location of the military base and the officers' residential area in the territory of the Krustpils castle.

9 Interview, 21 May 2015.

${ }^{10}$ An estimated 75,000 to 100,000 people, including family members, which was a significant number considering that in the early 1990s the proportion of ethnic Latvians in the Latvian population was only a little over 50\% (Jundzis 2014: 12-13). 
11 "Agreement between the Government of the Republic of Latvia and the Government of the Russian Federation on the social protection of the retired military personnel of the Russian Federation and their family members residing in the territory of the Republic of Latvia", and "Agreement between the Republic of Latvia and the Russian Federation on terms, time limits, and the procedure for a complete withdrawal of the armed forces of the Russian Federation and the legal status thereof during the withdrawal from the territory of Latvia" (Upmalis et al. 2006; Jundzis 2014).

${ }^{12}$ According to the homepage data of Mārciena parish, there are three companies involved in the timber business there: Märciena Wood, Damaksnis, and ILBU (see http://www. marciena.lv/marcienas-pagasta-uznemumi; last accessed on October 2, 2017).

${ }^{13}$ Publicly available data show the ethnic diversity of the Mārciena population. In addition to Latvians, Russians, Belarussians, Gypsies, Poles, Ukrainians, Lithuanians and others live there. The Mārciena website shows data from 2006: the total number of inhabitants - 1164, Latvians - 855 (73.5\%), Russians - 179 (15.4\%), Byelorussians $31(2.7 \%)$ (see http://www.marciena.lv/turisms-marciena/skaitli-un-fakti, last accessed on October 2, 2017).

${ }^{14}$ Madona County was founded in 2009 and it incorporates the city of Madona and fourteen municipalities. This is the third largest county in Latvia and the largest in the Vidzeme region. The county covers approximately 2153.4 square kilometres and about 25,515 people live there (as of 1 January 2016). The distance between Riga and Madona is 166 kilometres.

${ }^{15}$ A museum in Zeltini (in the Alūksne region) attempted to convert the former Soviet army nuclear missile base near Zeltini to a tourist attraction (see http://www.vietas. lv/eng/objekts/bijusa_psrs_strateiska_kodolrakesu_baze_pie_zeltiniem/, last accessed on October 3, 2017). However, for economic reasons, several owners of this particular plot of land refused to agree to create a common usage tourism object and to maintain it as a "burden of history".

${ }^{16}$ See Valsts aizsargājamo kultūras piemineklu saraksts (List of State-Protected Cultural Monuments), available at http://likumi.lv/doc.php?id=50976; last accessed on October 3, 2017.

${ }^{17}$ See the homepage of the spa hotel Mārcienas muiža. Available at http://www.marciena. eu/index.php/en/we/history, last accessed on October 3, 2017.

${ }^{18}$ Interview excerpt. Mārciena, May 2015.

${ }^{19}$ For example, the Odnoklasniki.ru (classmates) website. Available at https://ok.ru/, last accessed on October 3, 2017.

${ }^{20}$ For example, the Odnopolchane.net (fellow soldiers) website. Available at http://www. odnopolchane.net/, last accessed on October 3, 2017.

${ }^{21}$ For example, the Forumavia.ru website. Available at http://www.forumavia.ru/ forum/1/1/193544736490015480901227182111_5.shtml, last accessed on October 3, 2017.

${ }^{22}$ See https://fotki.yandex.ru/users/bir4onok/album/174326; https://www.youtube.com/ watch?v=g_sCPPeVW2g; https://www.youtube.com/watch?v=vJfOYUS_EBo; all last accessed on October 3, 2017. 
${ }^{23}$ See http://notebookvideo.ru/1h-gKvhZd8/rekviem_po_gorodkam_gde_my_sluzhili. html, last accessed on October 3, 2017.

${ }^{24}$ One part of the format of illustrations added to this song is available at https://www. youtube.com/watch?v=3-3Nlt8fQ0o, last accessed on October 3, 2017.

${ }^{25}$ One copy of the video-tape was given as a gift to the school, but it was not possible to see it. Unfortunately, the tape had been lost.

26 "Agreement between the government of the Republic of Latvia and the government of the Russian Federation on the status of Latvian burials in the territory of the Russian Federation and the status of Russian burial grounds in the territory of the Republic of Latvia" (2007). The agreement also determines the conditions under which the cemeteries are to be maintained by local municipalities.

\section{REFERENCES}

Angé, Olivia \& Berliner, David (eds.) 2016 [2014]. Anthropology and Nostalgia. New York \& Oxford: Berghahn.

Annist, Aet 2014. Losing the Enterprising Self in Post-Soviet Estonian Villages. In: Nicolette Makovicky (ed.) Neoliberalism, Personhood, and Postsocialism: Enterprising Selves in Changing Economies. Surrey \& Burlington: Ashgate, pp. 89-108.

Apine, Ilga \& Volkovs, Vladislavs 2007. Latvijas krievu identitāte: vēsturisks un sociologisks apcerējums. [Russian Identity in Latvia: A Historical and Sociological Study.] Riga: LU FSI.

Ashworth, Gregory J. \& Graham, Brian 2005. Senses of Place, Senses of Time and Heritage. In: Gregory J. Ashworth \& Brian Graham (eds.) Senses of Place: Senses of Time. Heritage, Culture and Identity. Aldershot: Ashgate Publishing, pp. 3-12.

Bonnett, Alastair \& Alexander, Catherine 2013. Mobile Nostalgias: Connecting Visions of the Urban Past, Present, and Future amongst Ex-Residents. Transactions of the Institute of British Geographers, Vol. 38, No. 3, pp. 391-402. DOI: 10.1111/j.14755661.2012.00531.x.

Boym, Svetlana 2001. The Future of Nostalgia. New York: Basic Books.

Cimdiṇa, Agnese \& Raubiško, Ieva 2012. Cilvēks un darbs Latvijas laukos. Sociālantropologisks skatījums. [Man and Work in the Latvian Countryside: A Social and Anthropological View.] Riga: Zinātne.

Davis, Fred 1979. Yearning for Yesterday: A Sociology of Nostalgia. New York: Free Press.

Demski, Dagnosław \& Czarnecka, Dominika 2015. Mapping Meanings in the Post-Soviet Landscape of Borne Sulinowo. Latvijas Vēstures Institūta Žurnāls, No. 2 (95), pp. 96120. Available at http://www.lvi.lv/lv/LVIZ_2015_files/2numurs/D_Demski_D_ Czarnecka_Mapping_LVIZ_2015_2.pdf, last accessed on October 3, 2017.

Dribins, Leo \& Šṇitṇikovs, Aleksejs (eds.) 2007. Pretest̄̄ba sabiedrūbas integrācijai: Cēloṇi un sekas. [Resistance to Integration of the Society: Causes and Consequences.] Riga: LU FSI, İUMSILS.

Dzenovska, Dace 2011. Notes of Emptiness and the Importance of Maintaining Life. The Anthropology of East Europe Review, Vol. 29, No 2, pp. 228-241. Available at https://scholarworks.iu.edu/journals/index.php/aeer/article/view/1248/1337, last accessed on October 3, 2017. 
Dzenovska, Dace 2013. The Great Departure: Rethinking National(ist) Common Sense. Journal of Ethnic and Migration Studies, Vol. 39, No. 2, pp. 201-218. http://dx.doi. org/10.1080/1369183X.2013.723254.

Grigas, Agnia 2013. The Politics of Energy and Memory between the Baltic States and Russia. Surrey \& Burlington: Ashgate.

Halbwachs, Maurice 1950. Space and the Collective Memory. In: Maurice Halbwachs. The Collective Memory. Available at http://web.mit.edu/allanmc/www/hawlbachsspace. pdf, last accessed on October 3, 2017.

Hanovs, Deniss \& Vinnika, Irina 2006. Russians and Russian-Speaking Population in Latvia: Diaspora and Technologies Cultural Memory. In: Žaneta Ozoliṇa (ed.) Expanding Borders: Communities and Identities. Proceedings of International Conference Riga, November 9-12, 2005. Riga: LU Akadēmiskais apgāds, pp. 185-208.

Iltnere, Astrida (ed.) 2002. Latvijas pagasti: Enciklopēdija. [Parishes in Latvia: Encyclopaedia.] Vol. 2. Riga: Preses Nams.

Jundzis, Tālavs 2014. Krievijas karaspēka izvešana no Latvijas 1992-1994: Diplomātijas uzvara vai politiska piekāpšanās? [Removal of Russian Federation Armed Forces from Latvia: A Diplomatic Success or Political Concession?] Latvijas Zinātņu Akadēmijas Vēstis, Section A, Vol. 68, No. 3-4, pp. 4-23. Available at http:// www.lza.lv/index.php?option=com_content\&task=view\&id=2263\&Itemid=400, last accessed on October 3, 2017.

Kaprāns, Mārtiṇš 2013. Padomju laika sociālās reprezentācijas latvijas sabiedriskajā domā (2004-2012). [The Social Representations of the Soviet Period in Latvian Public Opinion (2004-2012).] Latvijas Vēstures Institūta Žurnāls, No. 2 (87), pp. 102138. Available at http://www.lvi.lv/lv/LVIZ_2013_files/2numurs/M_Kaprans_ Padomju_laika_socialas_LVIZ_2013_2.pdf, last accessed on October 4, 2017.

Kaprāns, Mārtiṇš \& Procevska, Olga 2013. Latvijas sociālās atminas monitorings: Zinojums Nr. 1. [Monitoring on Latvian Social Memory: Report No. 1.] Riga: University of Latvia. Available at http://www.academia.edu/3232032/Latvijas_ soci\%C4\%811\%C4\%81s_atmi\%C5\%86as_monitorings_Zi\%C5\%860jums_Nr._1, last accessed on October 4, 2017.

Krūmiṇš, Gatis 2017. Gan nacistiskā Vācija, gan staḷiniskā PSRS Otrajā pasaules karā bija Latvijas Republikas ienaidnieces. [Both the Nazi Germany and the Stalinist USSR in the Second World War Were Enemies to the Republic of Latvia.] Available at http:// www.va.lv/sites/default/files/2pk_2017.marts_.pdf, last accessed on October 4, 2017.

Linin̄š, Uldis 2013. Mārcienas pagasts. [Mārciena Parish.] Mārciena: Mārcienas pagasta pārvalde.

Ločmele, Klinta \& Procevska, Olga \& Zelče, Vita 2011. 8./9. maijs Latvijā. [May 8-9 in Latvia.] In: Nils Muižnieks \& Vita Zelče (eds.) Karojošā piemiņa: 16. marts un 9. maijs. [Warring Memories: 16 March and 9 May.] Riga: Zinātne, pp. 236274. Available at https://dspace.lu.lv/dspace/handle/7/31243, last accessed on October 4, 2017.

Lowenthal, David 1985. The Past is a Foreign Country. Cambridge: Cambridge University Press.

LR Satversme 1922. [Constitution of the Republic of Latvia.] Available at http://likumi. lv/doc.php?id=57980, last accessed on September 25, 2017.

Mežs, Ilmārs 1994. Latvieši Latvijā: Etnodemogrāfisks apskats. [Latvians in Latvia: An Ethno-Demographic View.] Riga: Zinātne. 
Mintaurs, Mārtiṇš 2012. Kultūras mantojums un vēsturiskā atmiṇa Latvijas PSR: Rīgas Lielo kapu rekonstrukcijas piemērs 20. gadsimta 60.-80. gados. [Cultural Heritage and Historical Memory Policy in the Latvian SSR: The Case Study of the Great Cemetery Reconstruction in Riga (1960s-1980s).] Latvijas Vēstures Institūta Žurnāls, No. 2 (83), pp. 62-88. Available at http://www.lvi.lv/lv/ LVIZ_2012_files/2numurs/M_Mintaurs_Kulturas_mantojums_LVIZ_2012_2. pdf, last accessed on October 4, 2017.

Mintaurs, Mārtiṇš 2013. Pieminekḷu valdes darbs Rīgas vecpilsētas arhitektūras mantojuma saglabāšanā vācu okupācijas laikā (1941. gada jūlijs - 1944. gada jūlijs). [Activities of the Monument Board in the Protection of Old Riga Architectural Heritage during the Nazi Occupation (July 1941 - July 1944).] Latvijas Vēstures Institūta Žurnāls, No. 2 (87), pp. 24-73. Available at http:// www.lvi.lv/lv/LVIZ_2013_files/2numurs/M_Mintaurs_Piemineklu_valdes_darbs_ LVIZ_2013_2.pdf, last accessed on October 4, 2017.

Muižnieks, Nils \& Zelče, Vita (eds.) 2011. Karojošā piemiņa: 16. marts un 9. maijs. [Warring Memories: 16 March and 9 May.] Riga: Zinātne.

Neiburgs, Uldis 1999. Latviešu karavīri Vācijas un PSRS armijās: galvenās problēmas. [Latvian Soldiers in the Armies of Germany and the USSR: Main Problems.] Konferences 'Latvijas Otrajā pasaules karā' rakstu krājums. [Proceedings of the Conference 'Latvia in the Second World War'.] Riga: Latvijas Valsts arhīvs, pp. 25-27. Available at http://www.archiv.org.lv/LVA/pdf/Tezes1999_latv.pdf, last accessed on October 4, 2017.

Neiburgs, Uldis \& Zelče, Vita (eds.) 2012 [2011]. (Divas) puses: Latviešu kara stāsti. Otrais pasaules karš karavīru dienasgrāmatās. [(Two Sides). Latvian War Stories. The Second World War in Soldiers' Diaries.] Riga: Mansards.

Noyes, Dorothy 2016. Humble Theory. Folklore's Grasp on Social Life. Bloomington: Indiana University Press.

Pickering, Michael \& Keightley, Emily 2006. The Modalities of Nostalgia. Current Sociology, Vol. 54, No. 6, pp. 919-941. http://dx.doi.org/10.1177/0011392106068458.

Puḳite, Iveta 2006. Divi miljoni eiro bijušo militāro teritoriju sakārtošanai. [Two Million Euro for the Adjustment of Former Military Territories.] Komersanta Vesstnesis, No. 36 (42), September 13. Available at http://www.kvestnesis. lv/?menu=doc\&id=143347, last accessed on October 4, 2017.

Puḳite, Iveta 2007. Palīgā degradētām teritorijām. [Help for Degraded Areas.] Komersanta Vēstnesis, No. 6 (62), February 7. Available at http://www.kvestnesis.lv/index. php?menu=doc\&id=152646, last accessed on October 4, 2017.

Reid, Bryonie 2005. 'That Quintessential Repository of Collective Memory': Identity, Locality and the Townland in Northern Ireland. In: Gregory J. Ashworth \& Brian Graham (eds.) Senses of Place: Senses of Time. Heritage, Culture and Identity. Aldershot: Ashgate Publishing, pp. 47-60.

Schecter, Jerrold L. \& Deriabin, Peter S. 1992. The Spy Who Saved the World: How a Soviet Colonel Changed the Course of the Cold War. New York: C. Scribner's Sons.

Sedikides, Constantine \& Wildschut, Tim \& Arndt, Jamie \& Routledge, Clay 2008. Nostalgia: Past, Present, and Future. Current Directions in Psychological Science, Vol. 17, No. 5, pp. 304-307. http://dx.doi.org/10.1111/j.1467-8721.2008.00595.x.

Skulte, Ilva 2016. Introduction. Framing the Future in the Past: Challenges for Memory Politics in the Baltics. In: Igors Gubenko \& Deniss Hanovs \& Vladislavs 
Malahovskis (eds.) The New Heroes - The Old Victims: Politics of Memory in Russia and the Baltics. Riga: Zinātne, pp. 8-15.

Truc, Gérôme 2011. Memory of Places and Places of Memory: for a Halbwachsian SocioEthnography of Collective Memory. International Social Science Journal, Vol. 62, No. 203-204, pp. 147-159. DOI:10.1111/j.1468-2451.2011.01800.x.

Upmalis, Ilgonis \& Tilgass, Ēriks \& Dinevičs, Jānis \& Gorbunovs, Anatolijs 2006.

Latvija - PSRS karabāze. 1939-1998: materiāli un dokumenti par Padomju armijas atrašanos Latvijā un tās izvešanu. [Latvia - the USSR Military Base. 1939-1998: Materials and Documents on the Presence of the Soviet Army in Latvia and Its Withdrawal.] Riga: Zelta grauds.

Ziemele, Ineta (ed.) 2001. Mazākumtautību (minoritāšu) integrācijas aspekti Latvijā. [Aspects of Integration of Minorities in Latvia.] Riga: Latvian University.

Zvirgzdiņš, Indulis 2003. Laiku un saimnieku maiṇa 'Patmalniekos'. [Change of Time and Owners in 'Patmalnieki'.] Stars, September 2.

\section{INTERNET SOURCES}

Centrālās statistikas 2011 = Centrālās statistikas pārvaldes datubāzes. [Central Statistical Database.] Available at http://data.csb.gov.lv/pxweb/lv/tautassk_11/ tautassk_11_tsk2011/TSG11-06.px/table/tableViewLayout2/?rxid=6b213b07c02d-49b7-badb-3d7ced80fdff, last accessed on September 25, 2017.

Commission of Historians. Available at http://www.president.lv/pk/content/?cat_id=7; last accessed on September 25, 2017.

Forumavia.ru. Available at http://www.forumavia.ru, last accessed on September 25, 2017.

Law on Land Reform in Rural Areas of the Republic of Latvia. Available at http://likumi. lv/doc.php?id=72849, last accessed on September 25, 2017.

Mārciena: Skaitl̦i un fakti. [Mārciena: Figures and Facts.] Available at http://www. marciena.lv/turisms-marciena/skaitli-un-fakti; last accessed on September 25, 2017.

Mārcienas pagasta uzñēmumi. [Mārciena Sustainable Enterprises.] Available athttp://www. marciena.lv/marcienas-pagasta-uznemumi; last accessed on September 25, 2017.

Odnoklasniki.ru. Available at https://ok.ru/, last accessed on September 25, 2017.

Odnopolchane.net. Available at http://www.odnopolchane.net/, last accessed on September 25, 2017.

Photographic Memories. Available at https://fotki.yandex.ru/users/bir4onok/album/174326, last accessed on September 25, 2017.

Spa hotel Mārcienas muiža. Available at http://www.marciena.eu/index.php/en/we/ history, last accessed on September 25, 2017.

Tūrisms Mārcienā. [Tourism in Mārciena.] Available at http://www.marciena.lv/turismsmarciena, last accessed on September 25, 2017.

Valsts aizsargājamo kultūras piemineklu saraksts. [List of State-Protected Cultural Monuments.] Available at http://likumi.lv/doc.php?id=50976, last accessed on September 25, 2017.

Video memories: Rekviem po gorodkam gde my sluzhili. [Requiem to the Cities Where We Served.] http://notebookvideo.ru/1h-gKvhZd8/rekviem_po_gorodkam_gde_ my_sluzhili.html, no longer available.

Zeltini. Available at http://www.vietas.lv/eng/objekts/bijusa_psrs_strateiska_kodolrakesu_ baze_pie_zeltiniem/, last accessed on October 4, 2017. 